\title{
A Survey of the Factors Affecting Market Patronage on the Path to Regional Development of Okitipupa, Nigeria
}

\author{
Rotowa O. O. \\ Department of Urban and Regional Planning, Federal University of Technology, Akure, Ondo State, Nigeria \\ Corresponding Author: *oorotowa@futa.edu.ng
}

\begin{abstract}
Markets are economic institutions serving as social entities. Diverse people based on ethnic groups, racial backgrounds and cultural traits are linked by a market. Socio-cultural, religious and political activities equally take place in the markets. This study was carried out in Okitipupa the regional headquarter of Ikale people of Ondo State. The sample size of 120 was selected by the purposive sampling technique, taking cognizance that they were fully representative of the populations of the study area. The questionnaires retrieved, were coded and analysed using SPSS (Statistical Package for Social Sciences) Version 16 computer programs and the Excel spreadsheet software. The findings of the study reveal that infrastructure such as road, water, electricity, and waste management facilities were in a deplorable state. This in effect created a problem for market women and a discomfort to patrons of the market. It is recommended that the community should embark on self-help development of the market, create market management committee, seek for the intervention from the government and provide sustainable redevelopment programs for quick improvement of the market.
\end{abstract}

Keywords: Market, Patronage, Region, Regional development, Okitipupa

\subsection{Introduction}

The Sustainable Development Goals (SDGs) are plans of action for people, planet and prosperity. They seek to strengthen universal peace in larger freedom. It recognizes that eradicating poverty in all its forms and dimensions, including extreme poverty, is the greatest global challenge and an indispensable requirement for sustainable development. Specifically, Goal 2 is to end hunger, achieve food security and promote nutrition and promote sustainable agriculture in particular. Target $2 \mathrm{c}$ of the SDG sought to adopt measures to ensure the proper functioning of food commodity markets and their derivatives. In addition, it is to facilitate timely access to market information, including food reserves in order to help limit extreme food volatility.

It has been observed that Africa's extensive rural areas contain the continent's greatest poverty concentrations of hunger and poverty (Baba-Mousa, 2005). Nevertheless, they also offer the greatest potential for near-term growth, through increased agricultural production and processing. Unlocking the potentials requires rural transport infrastructure adequately maintained to permit farmers to obtain inputs and information at reasonable cost and sell their output at realistic prices to cover their overall cost at regional and traditional markets.

The Okitipupa central market is located in Okitipupa local government area of Ondo State. The existence of this regional market as a formal transaction place with its own unique characteristics, offer a wide range of merchandise, especially for agricultural products and a face-to-face transaction. It has a direct relationship with history, culture, social interaction of the Ikale region and the settlements patronizing the market. Thus, in Okitipupa region, the existence of the market is inseparable with the growth and development and for the survival of the surrounding rural people. Certainly, the market has an impact on agricultural production and other daily products for local inhabitants. In spite of these, the major challenge threatening the functionality and sustainability of 
the market is poor infrastructure and accessibility, especially from agricultural production centres to the market. These problems had further affected the satisfactory functioning of the market, which is evident in the decline of socioeconomic development and poor interaction of activities in space, which has affected the revenue mobilisation capacity of the market, sustainability of the market and the general living condition of Okitipupa and the countryside which contain the rural people.

\subsection{Literature review}

Regional planning is the planned development of the resources of a unit area in order to maximize returns on investment and to improve the living conditions of the inhabitants of the area concerned (Barbour, 1972). It is a conscious attempt to demonstrate which, among several alternatives for development in any particular case will contribute to national income and Gross Domestic Product (GDP). Olamiju and Olujimi, (2011), submitted that regional planning is for a region or group of regions. A region by definition is a definite geographical setting which possesses the largest degree of homogeneity measured by the largest of economic, cultural, administrative and external indices to the largest number of objectives (Friedman and Alonso, 1968).

Planning region is an area displaying some coherence or unity of economic decision. It is an area large enough to enable substantial changes in the distribution of population and employment taking place within its boundaries, yet which is small enough for its planning problems to be seen as a whole. In retrospect, a planning region implies a specific geographical space (supra-urban space) created for the purpose of analysis, synthesis and planning (Glasson, 1974). Invariably, the presence or absence of uniformity in space is the central theme in the definition of a region. To qualify as a region, it must have a delineated geographic space.

\subsubsection{Marketing}

Marketing is the process of planning, executing the conception, pricing, promotion and distribution of ideas, goods and services to locate exchanges that satisfy individual and organizational objectives (Omole, 2003). It is a necessary activity that encompasses the entire business and is vital to sound business health. Marketing view the entire business from the customer's viewpoint, taking into account every aspect of the marketing mix from product to price, distribution channels and marketing communication (Adalemo, 1979). Marketing is a process that is intended to find, satisfy and retain customers while business makes a profit. Central to these definitions is the role of the customer and his relationship to the product (whether he considers the product or services to meet a need or want) (Nwafor, 1982). Market from Economics perspective is a social structure developed to facilitate the exchange of right services or product ownership. Market enable people, services, firms and products to be evaluated and priced (Olujimi, 2002).

The rate of market patronage varies with the location of the market, duration of marketing and the facilities within the market and accessibility to the market. The general problem associated with regional markets in Nigeria includes the shortage of infrastructural facilities, low level of patronage and the effect of public facilities (such as water supply, drainage, power supply, and sewage disposal and the income of the patrons of the market). In most African cities, the population has contributed significantly to the considerable expansion of the informal sector and the rising number of petty traders (Wikipedia, 2013 as cited in Omosuyi, 2014). This results in substantial increase in demand (by traders) for marketing infrastructure and related facilities. A significant increase in the supply and distribution of food (especially locally produced foodstuff), oversubscribed market stalls that lack basic storage facilities, parking spaces, sanitation and security facilities, characterizes the retail food trade (Olujimi, 2002).

\subsubsection{The marketing function}

The market is the lowest level of the economy where traditional exchange and barter take place within village groups or isolated tribes who produce virtually and daily. The dominant interest is the ingestion of local foodstuffs and craft product into the exchange economy by buying and selling. A market is a place which allows the purchaser and the seller to invent and gather information. It allows them to carry out exchange of various products and services. A market therefore refers to a place where the trading of goods and services take place. This can be a market place or a street. 
The marketing function is there so that the satisfaction of the buyers and sellers during a transaction can be ensured. The market generally depends on the adjustment of the price so that it can inform the participants involved in a transaction. This is done so that both buyers and sellers are well informed and can bargain the right price out and satisfy themselves somewhat. Another function of the market is to keep the prices under check and control fluctuations in supply and demand to reach locative efficiency.

Market therefore, connotes an authorized public concourse of buyers and sellers of commodities, meeting at a place more or less strictly limited or defined at an appointed time (Omole, 2002). Market centres are fundamental to the economic, social, cultural, religious and political life of the people. Omole (2002) submits that markets can grow anywhere there are goods to sell and where buyers are available for patronage. He equally posited that markets are man-made features established for the use of man.

\subsubsection{Periodicity of market}

Two basic classes of markets have been mentioned in literature, these are the daily and periodic markets. A further classification of markets include morning, full-day, night, periodic, provincial and inter kingdom markets (Omole, 2002). Nwafor (1982) held the view that a daily market requires the existence of many full-time traders and that it is a more convenient type of market in that it provides the daily needs to the people on a daily basis. It is pertinent to point out that the daily market is so significant that large towns in Nigeria have at least one large daily market. For example, Lagos has at least seven daily markets; Ibadan has ten, while cities like Aba, Onitsha and Kano have at least one daily market. The majority of the villages on the other hand have periodic markets, which usually hold at four to eight day intervals.

Jin and Kim (2003) developed a typology of discount shoppers based on shopping motives, store attributes and outcomes. The differences in store patronage and attitude towards retail store environments, leading to the devise of the shopping orientation segment were the focus of Kincarde and Moye (2003). They were of the opinion that consumer choice is related to the store location and what they have to offer, as well as a number of consumer specific factors such as social class, type of family unit, age and lifestyle, the amount of goods purchased and brand and store loyalty. The influence of usage situation and consumer shopping orientations has an impact on the importance of the retail store environment, which also affect sales, product evaluations and satisfaction (Bitner 1990). There are four categories of shoppers' motivations, which are: consumer based economies which tend to pay attention to price, quality and variety of merchandise; consumer-based on personality which tend to seek a personal relationship in the context of shopping; consumer ethical shopping by moral principles and certain types of protection from the store; and consumer apathy, weak implicated in shopping activities.

Marketing and behavioural science had demonstrated the breadth of consumer motives for shopping. Hoffmann (2004) submits that consumers were motivated by more than the utilitarian motive to get the desired items. Six forms of shopping activities based on motivation and behaviour identified are: adventure, social, gratification, idea, role and value shopping. Adventure shopping likens shopping to an adventure activity because consumers feel a different atmosphere due to a visit from one place to another and the urge to get the goods, services or new experiences. Social shopping is shopping activity driven by the desire to socialize with how to shop with friends. Gratification shopping is impulse shopping to get satisfaction as a result of previous shopping experience, besides aiming to relieve stress. Motives are the reasons behind the will of man to do anything different from one customer to another.

\subsubsection{Market infrastructure}

In economics, a market that runs under laissez-faire policy is a free market. It is free in the sense that the government makes no attempt to intervene through taxes, subsidies, minimum wages and price ceiling, etc. Market prices may be distorted by a seller with monopoly power or a buyer with monopoly power. Such price distortions can have an adverse effect on market participant's welfare and reduce the efficiency of market outcomes. Also, the relative level of organization and negotiation power of buyers and sellers markedly affects the functioning of the market. Markets where price negotiations meet equilibrium still do not arrive at desired outcomes for both sides are said to 
experience market failure (Wikipedia, 2011 as cited in Omosuyi, 2014). Markets are a system and systems have structure. The structure of a well-functioning market is defined by the theory of perfect competition. Well-functioning markets of the real world are never perfect, but basic structural characteristics can be approximated for real world markets, for example, many small buyers and sellers have equal access to information products and are comparable.

Efficient marketing infrastructure such as wholesale, retail and assembly markets and storage facilities is essential for cost effective marketing to minimize post-harvest losses and to reduce health risks. Market infrastructure is required at all stages of the supply chain, from local retail and assembly markets through to wholesale and retail markets in major urban centres. Governments and local authorities generally have a poor appreciation of the importance of markets and a reluctance to invest in them. As a consequence, markets are often congested, unhygienic and inefficient. They are also fire risks. Local authorities frequently see markets as revenue raising opportunities, not as institutions that necessitate investment. Although there have been significant developments with regards to supermarket development and the improvement of farm-to-agro processor linkages, the great bulk of food products are still distributed through more traditional channels using traditional market infrastructure. Food and Agricultural Organization (FAO) has for years concentrated on market infrastructure improvement, both through technical assistance projects with national and provincial governments and local authorities and through the publication of a wide range of guides on the topic (Gaurav and Hoffmann, 2004 as cited in Balogun, 2012).

Facilities and services that are relevant to the development of market centres as listed by (Balogun, 2011 as cited in Balogun 2012) are as follows:

i. Access roads within the market must be motorable for ease of movement of people and good, vehicles for loading of goods;

ii. The provision of adequate drainage system that is well maintained to guide against erosion at the market site;

iii. Provision of adequate toilet facility for the market users;

iv. Adequate parking space, loading and off-loading bays must be provided to guide against on-street parking;

v. Provision of hydrants in case of fire outbreak;

vi. Provision of adequate water supply;

vii. Social cultural facilities;

viii. Provision of health care facility in case of emergency;

ix. Provision of adequate waste disposal facility;

x. $\quad$ Provision of security services to safeguard properties; and

xi. Market council of elders in place saddled with the responsibility of managing the market.

It is disheartening to observe that markets in third world countries have many defects. These defects are physical, social and managerial, which, according to the Food and Agriculture Organization include, but not limited to, market management, which establishes no clear relationship between revenues and costs, leading to the market being under-funded, especially for repairs and maintenance (Kuye and Agbabiaka, 2016).

\subsection{Materials and Methods}

Many markets exist in Okitipupa region, which includes: Okitipupa main market, Okitipupa night market, Ode-Aye market, Ilutitun market, and Ikoya market. Others are Igbotako Omotosho, Mile 49 and Wekaye markets. Okitipupa main market is situated on Longitude $6^{\circ} 30^{\prime}$ North of the Equator and Latitude $4^{\circ} 48^{\prime}$ East of the Greenwich Meridian. It is the biggest market in Okitipupa region, with control by the Local and State Governments. Though it had been patronized for more than thirty (30) years, its present structure was built by the Mimiko Administration in 2011. It is patronized in 5 day interval and has about 150 lock-up shops. The research instrument used was a well-structured questionnaire, which was designed to elicit data on the condition of the central market. The questionnaire was written in English Language and was translated into Yoruba when the respondent is illiterate. 
The sample size for the study is 120 and was selected by the purposive sampling technique, taking cognizance that they were fully representative of the populations of the study. The 120 questionnaires were retrieved and analysed using SPSS (Statistical Package for Social Sciences) Version 16 computer programs and the Excel spreadsheet software.

\subsection{Results and Discussion}

\subsection{Characteristics of respondents}

Consumer evaluation of a regional market has a positive impact on their attitude towards it. For this reason, the identity of target groups in the region must be aligned with the needs of stakeholders. The results of gender disparities (Table 1) show that 52.5\% of respondents covered by the study are female while $47.5 \%$ are male. The implication of this is that a larger percentage of people patronizing Okitipupa central market as buyers and sellers are females. This is in conformity with earlier findings by Omole (2002) that market centres in most south western Nigeria are dominated by women. It further reveals that women should be considered in market planning for regional development.

Table 1: Sex of respondents in Okitipupa market

\begin{tabular}{|l|l|l|}
\hline Sex & Frequency & Percentage (\%) \\
\hline Female & 63 & 52.5 \\
\hline Male & 57 & 47.5 \\
\hline Total & 120 & 100 \\
\hline
\end{tabular}

Source: Field survey, 2016

Attitude towards a region reflects individual mental pictures and association that individuals hold with regard to a specific regional market. Locals or visitors know the regional market and rely on their own impressions and experiences, whereas, external stakeholders possess secondary information. The age of respondents in Okitipupa market (see Figure 1) shows that the highest percentage of respondents falls between the age limit of 36-45 years (30\%). This was followed by respondents who are within age bracket $18-25$ years $(23.3 \%)$. Respondents who were above 65 years were $13 \%$, while $10 \%$ of the respondents were in the age bracket 46-64 years. It can therefore be implied that the working group able-bodied, are the majority of people conducting marketing in the market.
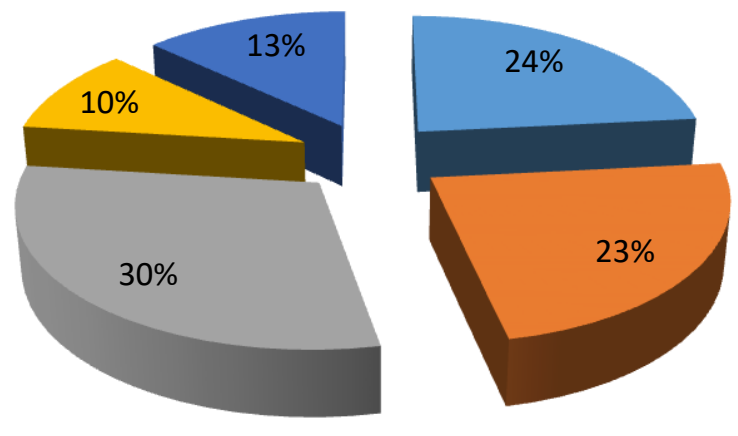

$$
\begin{aligned}
& 18 \text { - } 24 \text { years } \\
& 25 \text { - } 34 \text { years } \\
& 35 \text { - } 44 \text { years } \\
& 45 \text { - } 64 \text { years } \\
& \text { Above } 65 \text { years }
\end{aligned}
$$

Figure 1: Age of Respondents in Okitipupa Market Source: Field survey, 2016

The survey as reported in Table 2 reveals that respondents who earned less than 20000 Naira monthly were $30 \%$. In the same vain, respondents who earned between 21000 and 50000 Naira were $30 \%$. It was also discovered that while $28 \%$ earns between 60000 and 90000 Naira, $12 \%$ of respondents reports that they earn more than 100000 Naira monthly.

There is a nested constellation of regional marketing projects as an element that forms the attitude towards a region. It is expected that the attitude towards the regional marketing project influences the attitude towards the regional market. Figure 2 indicates the occupational distribution of respondents 
covered at Okitipupa market. It reveals that $24.2 \%$ of them are farmers. Next to this are the artisans $(21.7 \%)$ and the unemployed $(21.7 \%)$. The proportions of respondents who are traders are $16.7 \%$, while the civil servants were $7.5 \%$. The agrarian economy surrounding Okitipupa really account for the high volume of Agro-allied professionals captured in the survey. Hence, it is evident that most of the goods traded in the market will be agro-based.

Table 2: Monthly income of respondents

\begin{tabular}{|l|l|l|}
\hline Monthly Income $($ Naira $[\$ 1=$ N260]) & Frequency & Percentage \\
\hline Below 20000 & 36 & 30 \\
\hline $21000-50000$ & 36 & 30 \\
\hline $51000-90000$ & 33 & 28 \\
\hline Above 91000 & 15 & 12 \\
\hline Total & 120 & 100 \\
\hline
\end{tabular}

Source: Field survey, 2016

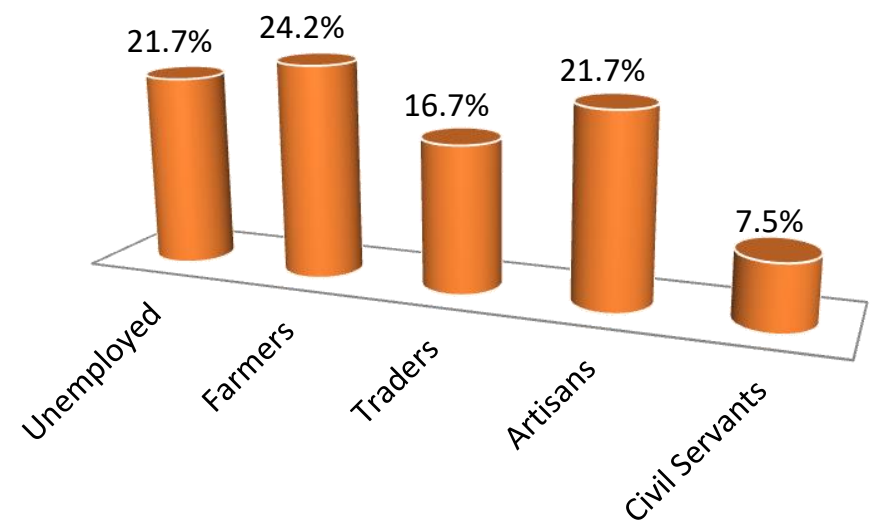

Figure 2: Occupation of respondents in Okitipupa market

Source: Authors' Fieldwork, 2016.

In addition, the marital status of respondents (see Figure 3) shows that 55\% of them were married. The study discovered that $19.2 \%$ of the respondents were single, while $15 \%$ are divorced. The proportion of the respondents who are widowed was $10.8 \%$. This reveals that the majority of the people patronizing the market were married men and women.

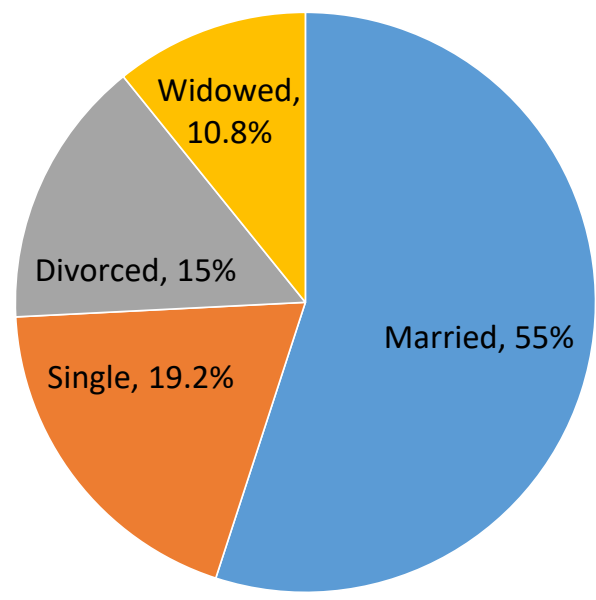

Figure 3: Marital status of respondents

Source: Authors' Fieldwork, 2016

Figure 4 depicts the educational level of the respondents; it shows that the majority of them (28.3\%) have completed the primary school. This was followed by respondents who are illiterate who cannot 
read nor write with understanding $(25 \%)$. Respondents who have secondary school education were $18.3 \%$, while 13.3\% have the National Certificate in Education (NCE). The proportion of respondents who have the polytechnic education and university education were $10 \%$ and $5 \%$ respectively.

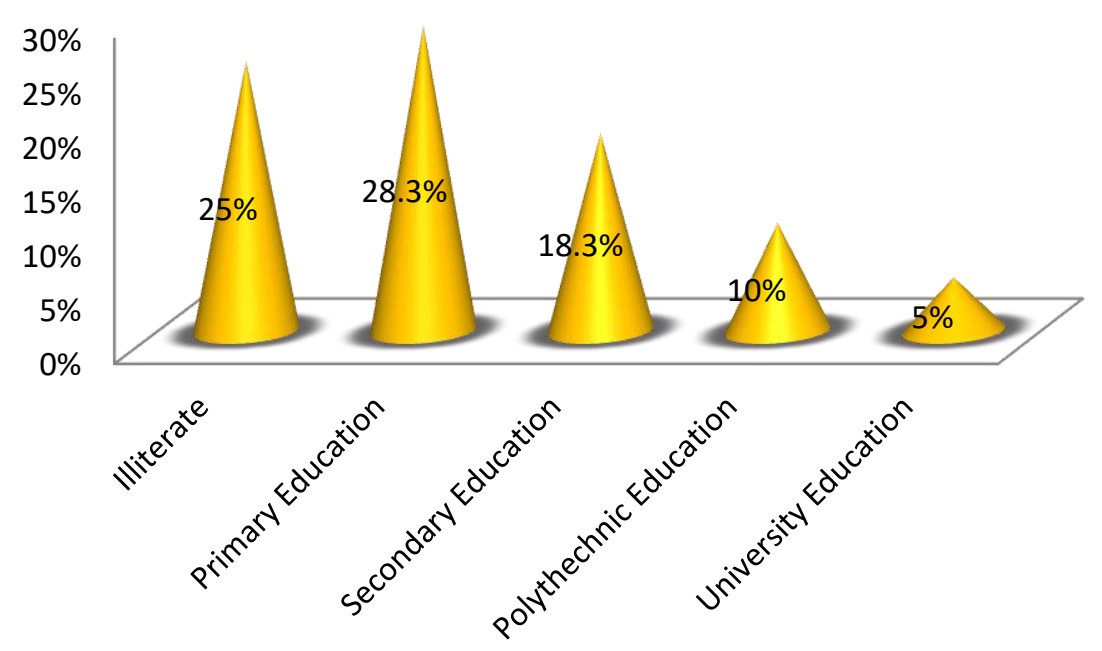

Figure 4: Educational level of respondents

Source: Authors' Fieldwork, 2016

\subsection{Facilities in Okitipupa market}

Accessibility is key to market patronage. This section presents the facilities available in Okitipupa regional market. Figure 5 shows accessibility to the market. The outcome from this research reveals that $30 \%$ of the roads were fairly accessible, particularly during market hours. On the other hand, $17 \%$ of the roads were hardly accessible. The other $11 \%$ of accessible roads were tarred hence, can be classified as good. Roads without kerbsides, untarred, with potholes and without drainage, and therefore are not accessible were $36 \%$. The high proportion of respondents claiming that road accessibility is poor in this study stems from the fact that the survey was conducted on market days. These are days when most of the roads are congested due to marketing activities.

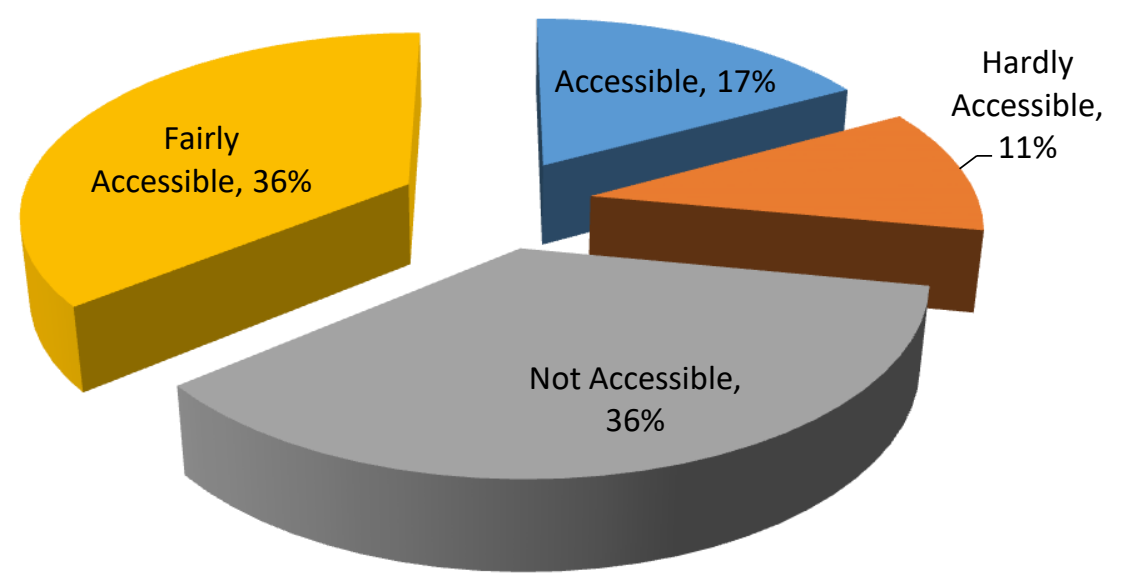

Figure 5: Road accessibility during market hour Source: Authors' Fieldwork, 2016.

The common methods for urinating and defecating in the market are through the Pit Latrine, Water Closet, and Open Defecation. The study reveals that $50.8 \%$ of market users use the pit latrine, while $17.5 \%$ use water closet to defecate (see Figure 6). The proportion of respondents that defecate openly 
are $31.7 \%$. The outcome of findings from the study is not unexpected because most markets in Nigeria are not equipped with improved toilet facilities (Kuye and Agbabiaka, 2016).

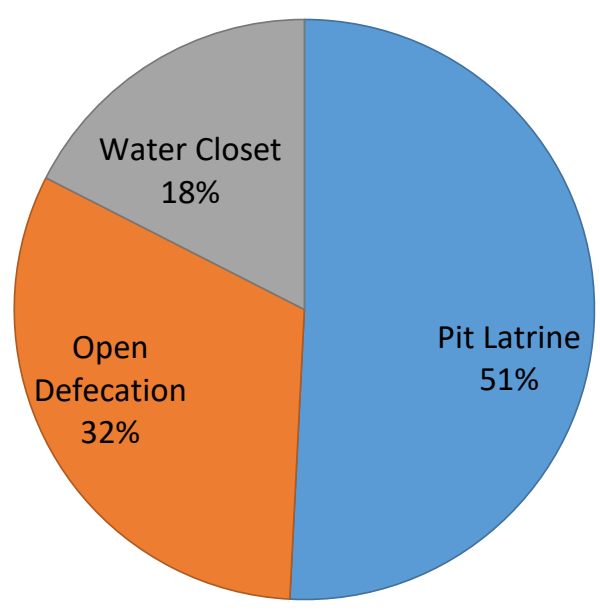

Figure 6: Type of toilet facility in Okitipupa market Source: Authors' Fieldwork, 2016.

The sources of water available in the market are: borehole, hand-dug well, pipe borne water, and steam water. The result of this survey reveals that $31.7 \%$ of the respondent use hand-dug wells as a water source. The proportion of respondents having access to pipe borne water is $28.3 \%$, while $25.8 \%$ have access to stream water. Respondents that depend on other sources of water is $1.7 \%$ (see Figure 7). The water from hand-dug wells often dries up during the dry season (October-March), and are only reliable for supply during the rainy season.

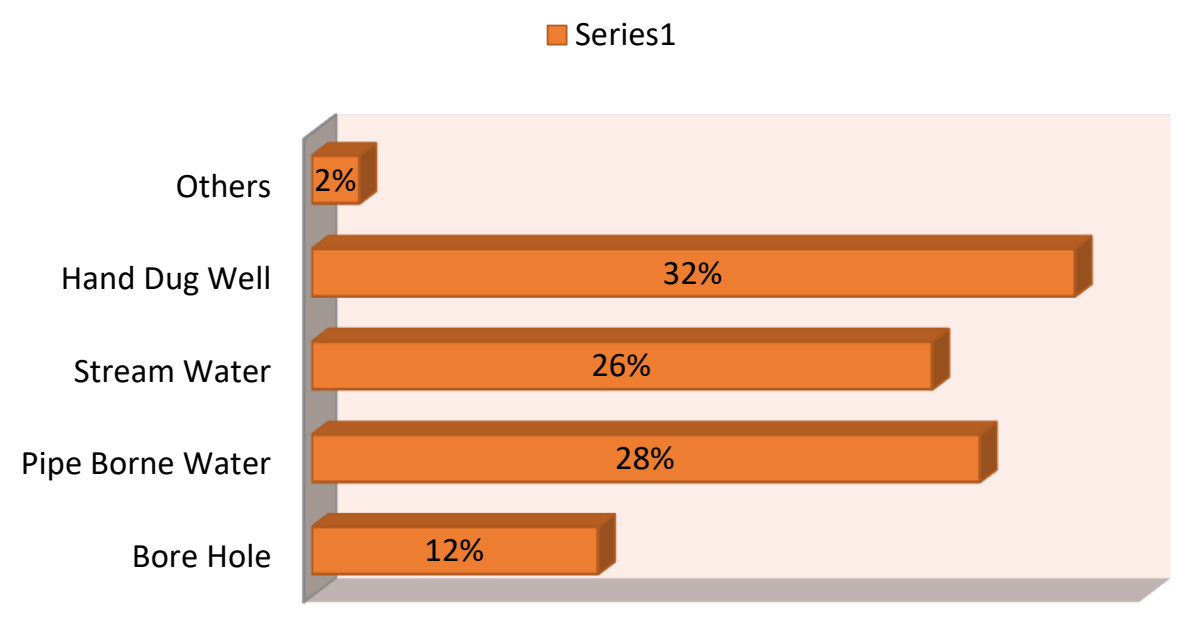

Figure 7: Water source in Okitipupa market Source: Authors' Fieldwork, 2016.

Wastes are generated in the market during market hours, which need to be evacuated. In Okitipupa central market, most of the solid wastes are disposed through burning (32.5\%). The proportion of wastes that are disposed through incineration is $24.2 \%$. Dumping of refuse inside gutters, nearby streams is carried out with $25.8 \%$ of respondents (see Figure 8). It was also discovered that only $17.5 \%$ of the refuse generated in the market is evacuated by Ondo State Waste Management Board (OSWMB). The proportion of wastes evacuated by OSWMB is paltry and there is the need to increase this proportion for environmental safety. 


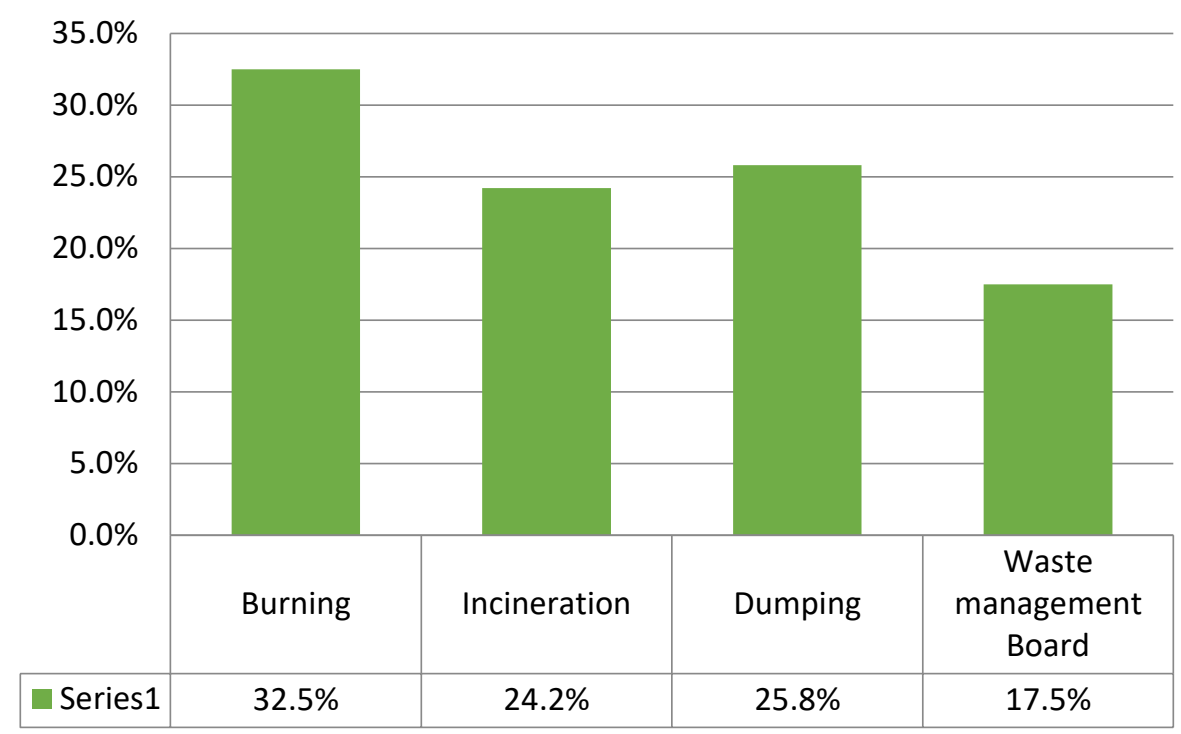

Figure 8: Mode of waste management in the market Source: Authors' Fieldwork, 2016.

Most of the stalls and stores in the market were connected to the public electricity main. Electricity supply was, however epileptic and was only available to the majority of the market between 6 and 12 hours a day. The sources of energy supply are majorly from the Benin Electricity Supply Company (BEDC) that supplies energy to about $43.3 \%$ of respondent (as shown in Figure 9). This is followed by $26.7 \%$ that uses generator, while $25 \%$ uses both public electricity from BEDC and generator. The rest of the respondents (5\%) have no source of energy.

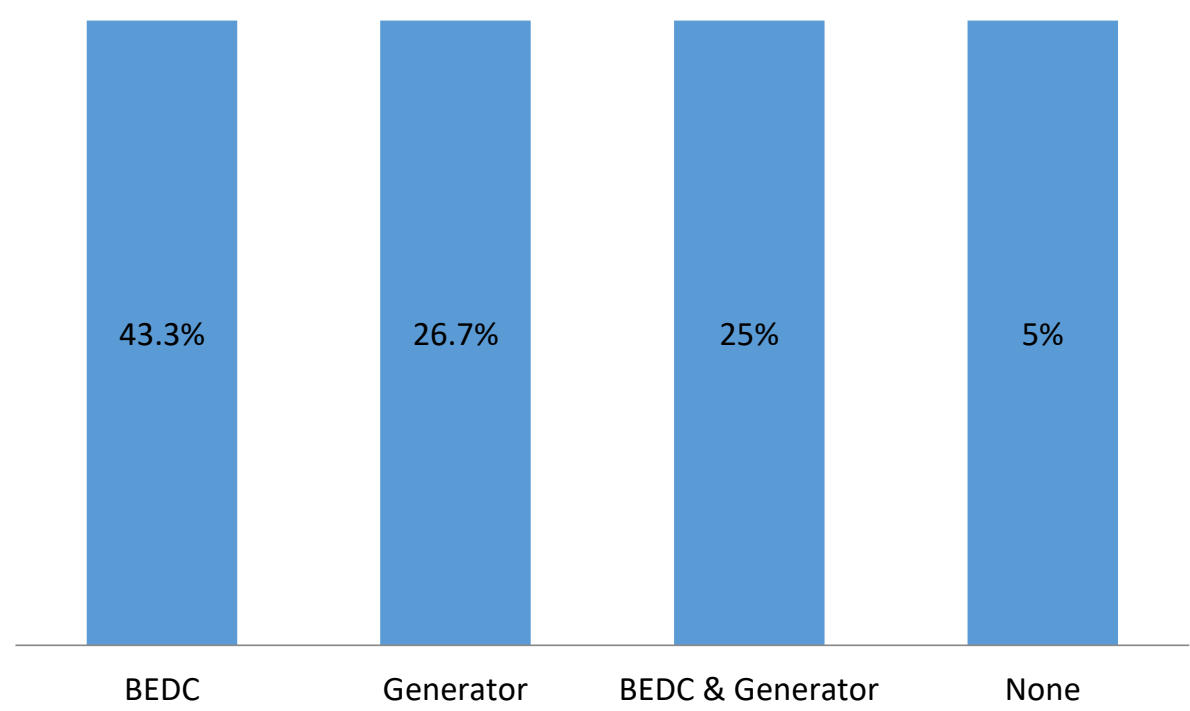

Figure 9: Sources of energy supply in the market

Source: Authors' Fieldwork, 2016.

\subsection{Levels of market patronage}

This section presents results and analyses of market patronage and regional development in Okitipupa. Okitipupa is the headquarters of the old Ikale region of the Ondo Province until 1976 when it became the headquarters of Okitipupa local government. It is therefore expected that the site of the market will have a significant effect on the region. The research finding from this study (Figure 10) reveals that the majority of the goods on display are food items (49\%), such as garri, bean, cassava yam and others. This was followed by trading in clothing and electronics $(40 \%)$. The proportions of traders of raw materials are $30 \%$, while $1 \%$ deals on other goods. 


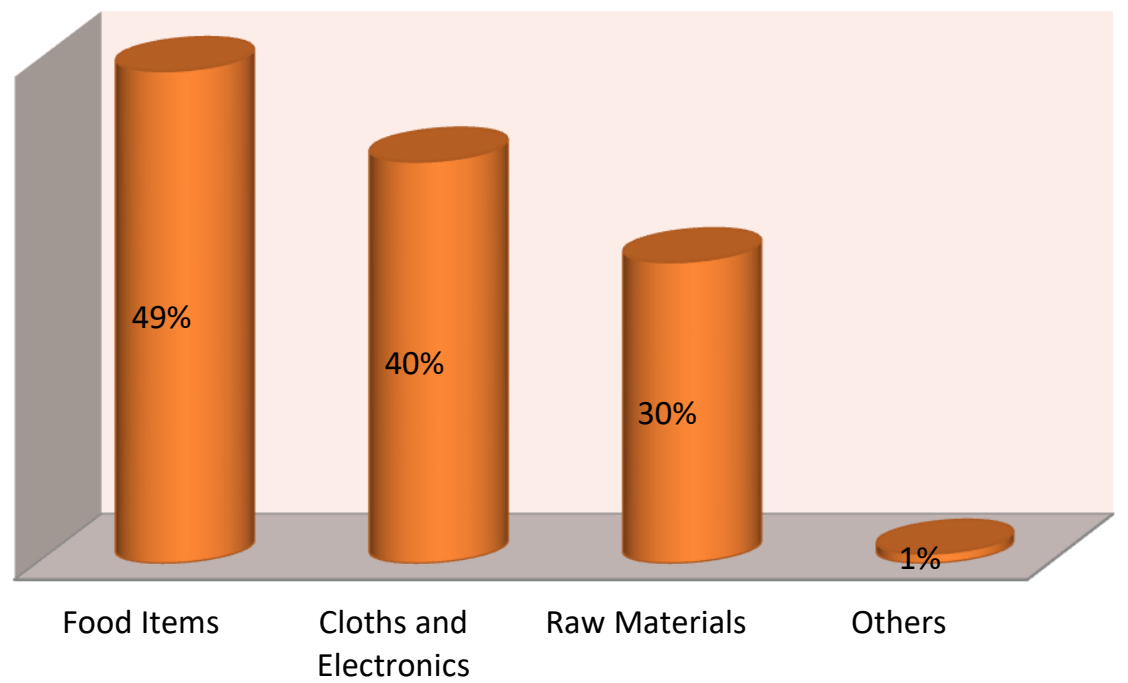

Figure 10: Classes of goods sold in Okitipupa market Source: Authors' Fieldwork, 2016.

Figure 11 shows the positive impacts of the market in the region; $25 \%$ of respondents' affirmed that the market provides jobs for them. On the other hand, $29 \%$ get infrastructural development through the market, while $21 \%$ reported that the market contributed to community development of the region. The proportion of respondents who claimed that they derive other benefits from the market was $25 \%$. This implies that the location of this market as attested to by the respondents has positive impacts on the development of the region in terms of infrastructure and employment generation among others. Hence, it can be concluded that it contributes to the economic and social development of the area.

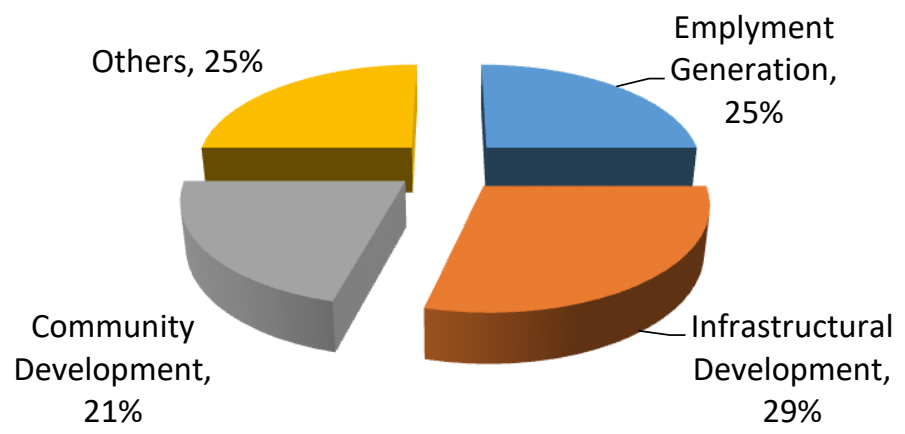

Figure 11: Positive effects of Okitipupa market location on the community Source: Authors' Field, 2016

The respondents were asked to comment on the negative effect of the location of the market. Figure 12 show that the highest on the list of such effects was noise pollution accounting for $34 \%$. This was followed by land pollution due to various items being traded in the market. The problem of crowding due to over population accounts for $20 \%$ of the negative effects as submitted by respondents. Traffic congestion was reported as a problem caused by the market by $18 \%$ of respondents. Other negative effects were mentioned by $4 \%$ of the respondents as part of the negative effects of the regional market. 


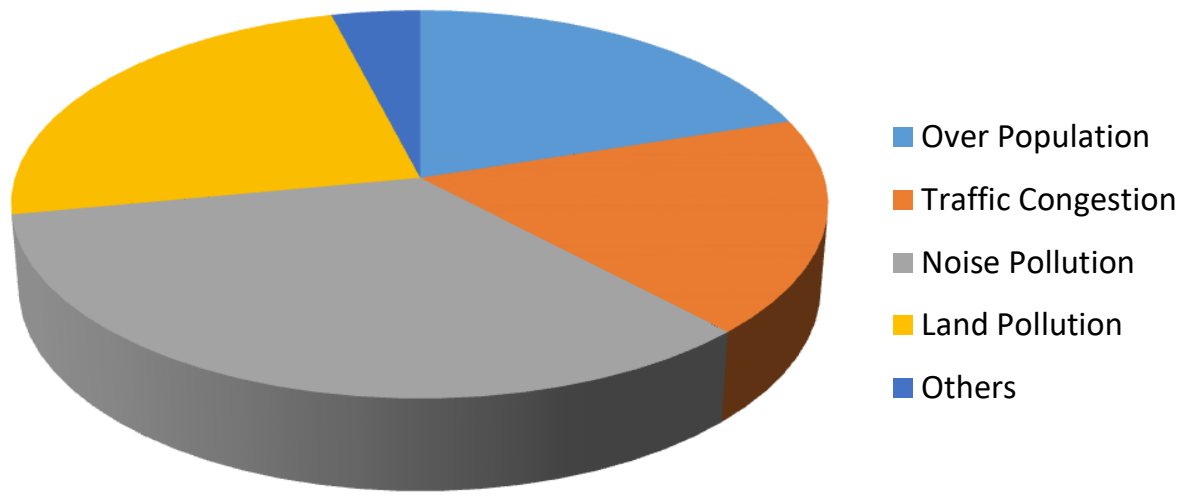

Figure 12: Negative effects of market location Source: Authors Fieldwork, 2016

The research reveals the factors that affect the level of market patronage in the study area (see Figure 13). The first such factor is a dirty environment as adduced to by $24 \%$ of the respondents. The next factor is the bad road as submitted by $24 \%$. In addition, $23 \%$ attribute low patronage to inadequate market facilities. Also, $21 \%$ of respondents submits that long distance from the market constitute a deterrent to market patronage, while $8 \%$ are of the opinion that inhospitable sellers constitute an adverse effect on market patronage.

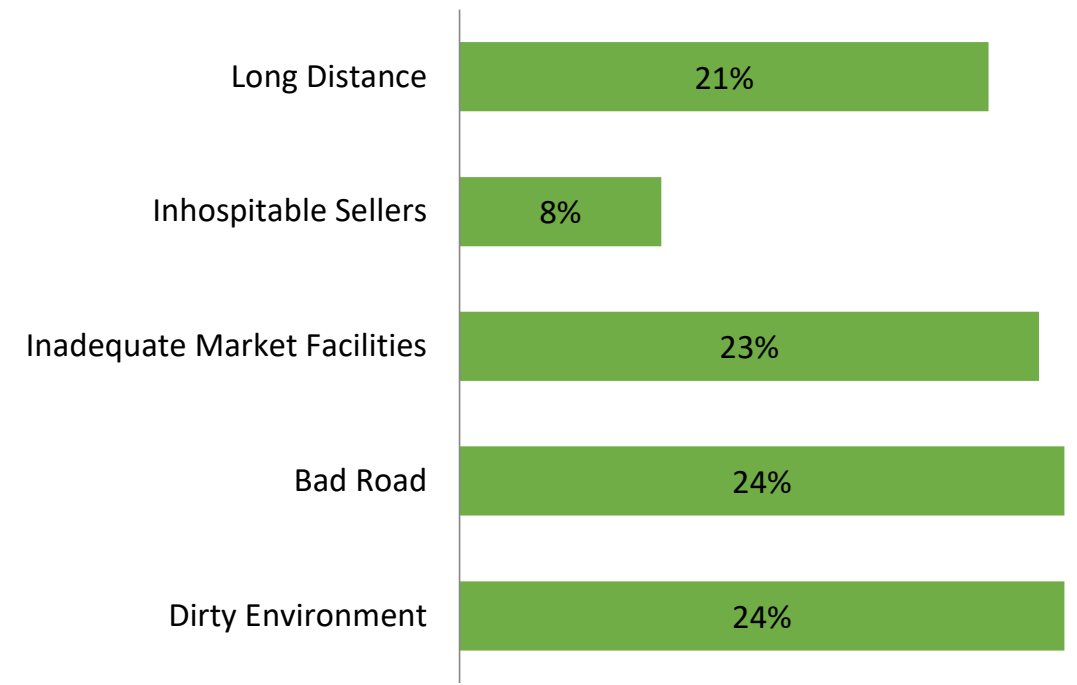

Figure 13: Factors affecting patronage in Okitipupa market Source: Authors' Fieldwork, 2016.

The research further observed that the level of patronage of the market was faced with some problems as shows in Table 3. It was observed that the seasonality of production was cited by $35 \%$ of the respondent. This was followed by $24.2 \%$ of the respondents who agreed that problem of the high cost of stores is a problem. Lack of or inadequate stalls was cited by $20 \%$ of respondents, while $13.3 \%$ agreed that the market has the problem of insecurity, while $7.5 \%$ submits that poor transportation is a problem facing the market. 
Table 3: Solution to problems of market patronage

\begin{tabular}{|l|l|l|}
\hline Factors affecting Levels of Patronage & Frequency & Percentage (\%) \\
\hline Lack of Stalls & 24 & 20 \\
\hline Seasonality of Production & 42 & 35 \\
\hline High Cost of Stalls and Stores & 29 & 24.2 \\
\hline Insecurity & 16 & 13.3 \\
\hline Poor Transportation & 9 & 7.5 \\
\hline Total & 120 & 100 \\
\hline
\end{tabular}

Source: Authors' Fieldwork, 2016

\section{Testing of Hypothesis:}

The hypothesis tested the condition of market facilities with level of patronage in Okitipupa regional market. The result revealed a correlation coefficient of $\mathrm{r}=0.12$ significant at $\mathrm{p}<0.05$ using $\mathrm{t}=\mathrm{r}$ SPOT (n-2) (1+r) according to Kothari (2004) a value of 3.28 was obtained which was higher that the table value of 1.67 and 2.91 at $\mathrm{P}<0.01$ and 0.05 respectively; hence, the null hypothesis was rejected. The alternate hypothesis was accepted that there is an association between market facilities and market patronage in Okitipupa region.

\subsection{Conclusion}

This study has brought into focus the market facilities available in Okitipupa central market and the level of patronage of the market. The main facilities that were available in the market are fairly accessible road characterised by on-street parking; the pit latrine as the main toilet; and hand-dug well as the main water source. Solid wastes generated are mostly disposed through burning, while the main electricity is from the national grid and generator. The products on display in the market include food items, clothes, electronics, raw materials, cement, plastics, building materials and so on. The positive impacts of the market are felt in the areas of employment generation, infrastructural development, and community development. On the other hand, the negative effects of the market are in the area of traffic congestion, noise pollution, and land pollution (through open defecation). In addition, the market is equally faced with problems of inadequate stores/stalls; seasonality of the produce in the market; high cost of stalls/stores; insecurity; and poor transportation.

It is recommended that the market be expanded and the Government should build more stalls/stores; the access road should be re-constructed and provided with a good drainage system. In addition, modern waste bins and trucks should be provided and complemented by an efficient and effective waste disposal system. The market should be equipped with public toilet equipped with adequate water.

\section{References}

Adalemo, A. I. (1979). Small Urban Centres in Nigeria's Development Strategy; the role of rural market centres, small urban centres in rural development in Africa. Africa Study, 1, pp. 128-130.

Baba-Moussa, (2005). Transport and the Millennium Development Goals in Africa. Ecowas Commission on Transport.

Barbour, K. M. (1972). Planning for Nigeria. University Press, Ibadan.

Bitner, M. J. (1990). Evaluating service encounters: the effects of physical surroundings and employee responses. Journal of Marketing, 54(2), pp. 293-312.

Friedman, U. and Alonso, W. (1975). Regional Policy: Reading in Theory and Application. MIT, Cambridge, Mass, Press, London.

Glasson, J. (1974). An Introduction to Regional Planning. Hutchinson Press Ltd, London.

Hoffmann, J. P. (2014). Generalized Linear Models: An Applied Approach. Person Education Inc. Store choice and patronage: a predictive modelling approach, 251. 
Jin, B. and Kim, J. O. (2003). A Typology of Korean, discount shoppers: Shopping motives store attributes and outcomes. International Journal of Service Industry Management, 14(3,4), pp. 396-419.

Kincarde, D. and Moye, L. (2003). Shopping orientation segments: Exploring differences in store patronage and attitude toward retail store environments among female consumers. International Journal of Consumer Studies, 27(1).

Kuye, O. A. and Agbabiaka, H. (2016). Assessment Of Market Facilities And Locational Effects On Adjoining Neighbourhoods In Nigerian Urban Centers : Empirical Evidence From Akure, Nigeria, (November).

Nwafor, J. C. (1982). Marketing System and Periodic Market, Nigeria. In: Maps. Pp. 114. ISBN 0340184256

Olamiju, I. O. and Olujimi, J. (2011). Regional Analysis of Locations of Public, Educational Facilities in Nigeria: The Akure Region Experience. Journal of Geography and Regional Planning, 4(7), pp. 428-442.

Olujimi, J. A. B. (2000). Sustainable Development of Rural Infrastructure in Nigeria: An Approach to Poverty Alleviation. International Journal of Economic Development, 1, pp. 148-159.

Olujimi. J. A. (2002). Patronage Pattern of Rural Household to health facilities in Owo region, Nigeria. Unpublished Ph.D. thesis, Department of Urban and Regional Planning, Federal University of Technology Akure.

Omole, F. K. (2003). A spatial distribution of market centres in the development of Osun State, Nigeria. Journal of the Nigeria Institute of Town Planners, 16, pp. 69-84.

Omosuyi, M. F. (2014). Market Patronage and Regional Development (A Case Study of Okitipupa Main Market) Okitipupa Ondo State, Nigeria, an unpublished B TECH, Thesis. The Federal University of Technology, Akure, Nigeria.

Rhee, H. and Bell, D. R. (2002). The Inter-Store Mobility of Supermarket Shoppers. Journal of Retailing, 78, pp. 225-237. 